\title{
Effect of Planting System on Productivity, Dry-matter Partitioning and Carbohydrate Content in Above- ground Components of 'Flordaprince' Peach Trees
}

\author{
T. Caruso ${ }^{1}$ \\ Dipartimento di Arboricoltura, Botanica e Patologia vegetale, Università degli Studi di Napoli 'Federico \\ II', 80055 Napoli, Italy \\ P. Inglese ${ }^{2}$ and F. Sottile ${ }^{3}$ \\ Istituto di Coltivazioni Arboree, Università degli Studi di Palermo, 90128 Palermo, Italy
}

F.P. Marra ${ }^{4}$

Dipartimento di Agrochimica ed Agrobiologia, Università degli Studi di Reggio Calabria, 89061 Reggio Calabria, Italy

\begin{abstract}
Additional index words. Prunus persica, central leader, Y shape, harvest index, starch
Aвstract. Vegetative growth, fruit yields, and dry matter partitioning within above-ground components were assessed during three growing seasons for trees of an early ripening peach (Prunus persica L. Batsch 'Flordaprince' on GF 677 rootstock) trained either to a free standing central leader $(930$ trees/ha) or to $Y$ shape $(1850$ trees/ha). Individual trees trained to central leader gave higher fruit yield, had a significantly greater leaf area and accumulated more dry mass in above-ground components per tree than Y shape trees. The training systems did not differ in terms of yield efficiency (yield per trunk cross-sectional area) and leaf area index (LAI), but Y shape trees had a higher harvest index and fruit dry mass per ground area than central leader. Four years after planting, Y shape had $35 \%$ higher yield per hectare than central leader. The relative contribution of 1-year-old wood, shoot and leaf to the dry mass of the tree decreased with tree age. Four years after planting the dry matter partitioned to the $>1$-year-old wood components represented $60 \%$ of the total tree mass (excluding fruit) in both the training systems. Central leader trees had the highest relative vegetative growth rate during stage III of fruit development. Most starch depletion occurred from dormancy to pit hardening from the canopy main storage pools (>1-year-old wood), and was higher for central leader than Y shape trees. For the ease of management and the high crop efficiency, the $Y$ shape can be successfully used for peach high density planting systems.
\end{abstract}

In peach, high-density orchards depend on the choice of an appropriate training system rather than on the use of dwarfing rootstocks or cultivars which are not available yet (Loreti et al., 1990). Peach trees trained either to palmette or free spindle and $Y$ shape show different patterns of sunlight interception and withincanopy distribution, and the $\mathrm{Y}$ shape allows a more uniform sunlight distribution within the canopy than does free spindle (De Salvador and DeJong, 1989). Seasonal and long term patterns of canopy development of different training systems may result in large differences in canopy volumes, leaf area and leaf density as well as tree productivity, fruit distribution (Sansavini et al., 1985) and overall fruiting efficiency (Loreti et al., 1990). Different patterns of sunlight distribution have been associated with leaf physiological and morphological attributes, such as carbon exchange rate (Marini and Sowers, 1990), chlorophyll and N content (DeJong and Doyle, 1985), and specific leaf dry weight (Weinbaum et al., 1989). Furthermore, sunlight distribution influences flower initiation, fruit set and fruit quality, particularly size, color

Received for publication 27 Aug. 1997. Accepted for publication 17 Aug. 1998. Research undertaken in the framework of the Project Mi.P.A. Frutticoltura, Subproject Tecnica colturale. Each author contributed equally to setting up and carrying out this research. The cost of publishing this paper was defrayed in part by the payment of page charges. Under postal regulations, this paper therefore must be hereby marked advertisement solely to indicate this fact.

${ }^{1}$ Professor of horticulture.

${ }^{2}$ Professor of horticulture.

${ }^{3}$ Graduate research assistant.

${ }^{4}$ Researcher and soluble solids content, depending on the seasonal trend of sunlight availability (Corelli Grappadelli and Coston, 1991; George et al., 1996; Marini et al., 1991).

The efficiency of a training system may be evaluated in terms of 'light use' (Robinson and Lakso, 1991), that is the capacity to maximize assimilate distribution into fruit yield (Chalmers, 1989). Long-term and seasonal priorities for allocation of dry matter and reserve carbohydrate to various components of the shoots and roots of peach trees depend on tree age (Chalmers and van Den Ende, 1975), genotype (DeJong and Doyle, 1984; Scorza et al., 1986), rootstock (Caruso et al., 1995, 1997b; Gaudillère et al., 1992; Glenn and Scorza, 1992), fruit load (Miller and Walsh, 1988), and ripening time (Grossmann and DeJong, 1995). Chalmers and van Den Ende (1975) suggested that the age, or size, at which the tree optimizes dry matter partitioning to fruit may change with orchard design (plant spacing) and/or plant management (training system). They also suggested that early yielding performances of high density peach orchards may be related to a decrease of the size or age at which the trees attain their optimum dry matter partitioning to the fruit.

During late dormancy an extensive mobilization of reserve carbohydrates from perennial components occurs to support early spring growth (Inglese and De Salvador, 1996). The extent of starch mobilization from storage pools is also associated with the vigor of the scion-rootstock combination (Caruso et al., 1997b) and regeneration of starch reserves occurs from fruit harvest to leaf abscission (Inglese and De Salvador, 1996).

However, there is a lack of information on the influence of the training system on seasonal and long-term dry matter and non- 
structural carbohydrate partitioning between vegetative and fruit growth in peach trees, and few data are available on the effect of apple training systems on dry matter and seasonal carbohydrate partitioning into tree components (Stutte et al., 1994). A better understanding of carbon economy in peach (Grossman and DeJong, 1992) as related to the training system may eventually contribute to improved orchard management.

The main objectives of this study were to study 1) the long term dry matter partitioning within above-ground components, 2) the seasonal pattern of sink competition between vegetative and fruit growth, and 3) the repartitioning of carbohydrate reserves during fruit development period in trees on two peach planting systems that have been widely planted in southern Europe.

\section{Materials and Methods}

Dormant buds of the low chill and early ripening peach Prunus persica (L.) Batsch 'Flordaprince' were grafted in September 1990 on ex vitro GF 677 (Prunus persica $x$ Prunus amygdalus Batsch.) rootstocks planted in January 1990 at Sciacca, 37 30' $\mathrm{N}$ and 120 $\mathrm{m}$ above sea level. The soil was sandy loam with pH 7.3 and $5.1 \%$ active lime. Trees were trained either to a free standing central leader (modified free spindle) or to a free standing Y shape. Tree spacing was $4.5 \times 2.4 \mathrm{~m}(930$ trees/ha) for trees trained to freestanding central leader and $4.5 \times 1.2 \mathrm{~m}$ (1850 trees/ha) for those trained to $\mathrm{Y}$ shape.

The orchard was planted in a complete randomized block design with 5 replications of 15 trees per training system. Trees were trained Y shape, which differs from the Tatura trellis (Chalmers, 1975) both in the lack of trellis and steel wires running lengthwise on each side of the trees, and for the shorter length of the two primary scaffolds set during the 'first leaf' season by orienting two laterals at 30 to $40 \mathrm{~cm}$ from the crown at a $35^{\circ}$ angle to the vertical. Tree height was limited to $2.5 \mathrm{~m}$ by pruning. Trees trained to a free-standing central leader consisted of a main stem with permanent lower scaffolds formed by three primary branches selected at $\approx 50$ to $60 \mathrm{~cm}$ above the ground. These branches are 20 to $25 \mathrm{~cm}$ apart and, with respect to the horizontal plane, form angles of $120^{\circ}$, and imply a larger within-row spacing than Y shape trees. Small fruiting branches develop along the stem upwards, and are annually renewed after harvest. Trees were maintained at a height of 2.5 to $2.8 \mathrm{~m}$ by heading back the leading apical shoot to a vigorous side shoot trained up as the new leader (Caruso et al., 1997a). In both training systems, trees were summer pruned with a light preharvest pruning (early May) to remove suckers and improve light penetration within the canopy, followed by a severe postharvest pruning (June) to shorten 1-year-old shoots to the most proximal newly formed shoot, and remove young feathers (Caruso et al., 1997a). Dormant pruning was limited to the removal of the previous year fruiting shoots.

The experimental plot received routine horticultural care in terms of fertilization, irrigation, pest control, and floor management (Caruso et al., 1997b). Fruit were hand thinned 3 weeks after fruit set, leaving one fruit about every $15 \mathrm{~cm}$ along the fruiting shoots.

GROWTH AND DRY MATTER PARTITIONING. Five trees per training system were sampled at each sampling date to determine dry matter distribution within above-ground components. Trees were destructively sampled according to the following schedule: fruit harvest 1992, 1993, and 1994, (12 June 1992, 10 June 1993, and 11 June 1994); during dormancy (5 Jan. 1993 and 12 Jan. 1994); at fruit set (10 Mar. 1994); and pit hardening (27 Apr. 1994). Aboveground components were partitioned into fruit and leaves (when present), current season's shoots, 1-year-old wood, and >1-yearold wood. The length of current-season's shoots and the older wood and their fresh mass were determined immediately during sampling. Subsamples of $1 \mathrm{~kg}$ fresh weight were weighed and then dried at $60^{\circ} \mathrm{C}$ to constant weight for dry mass determination and specific leaf weight calculation. At fruit harvest, trunk diameter was measured at $30 \mathrm{~cm}$ above the soil surface to calculate trunk cross-sectional area (TCA). Leaf area was measured on a subsample of 250 leaves per tree with an area meter (LI-3100; LICOR, Neb.). Total leaf area (LA) per tree was calculated from the ratio of leaf area to leaf dry weight of the sample and the total leaf dry weight of the tree. Leaf area index (LAI orchard) and dry matter production per leaf area were then calculated. A modified harvest index (HI) was calculated (Caruso et al., 1997b) as the ratio between the dry matter allocated to the fruit vs. dry matter allocated to the annual canopy growth (shoot, leaf, and fruit).

Productivity ANd Fruit Parameters. Fruit yield per tree was measured in terms of fruit count and fresh weight $(\mathrm{kg} / \mathrm{tree})$ at commercial maturity. Yield efficiency was calculated as fruit yield per tree $(\mathrm{kg})$ to TCA. Ten individual fruit per tree (fifty per treatment) were sampled to determine fresh and dry fruit weight, total soluble solids (TSS), total titratable acidity (TTA), and soluble carbohydrates (glucose, fructose, sorbitol, sucrose). TSS was measured on the homogenized juice obtained by flesh slices taken along the central band of the fruit and measured with a digital refractometer (ATAGO Pr-1, Tokyo); TTA (expressed as malic acid) was determined by a $\mathrm{pH}$ meter (Gibertini, Milan, Italy). Glucose, fructose and sucrose were determined (Caruso et al., 1997b) using, respectively, hexokinase and glucose-6-phosphate dehydrogenase, hexokinase and phosphoglucose isomerase, and after enzymatic inversion to D-glucose and D-fructose by the enzyme $ß$-fructosidase (test combination, 716 260, Boehringer, Heidelberg, Germany). The absorbance was read at $340 \mathrm{~nm}$ (Shimadzu UV-2100 spectophotometer, Kyoto, Japan).

STARCH Content. At fruit harvest in 1993 (10 June) and throughout the 1994 growing season, at fruit set (10 Mar.), pit hardening (27 Apr.) and fruit harvest (11 June), starch content was determined on five replicates of 1-year-old wood and on >1-yearold wood according to the procedure described by Caruso et al. (1997b). The insoluble pellet resulting from ethanol extraction was used for starch determination. Starch was digested for $15 \mathrm{~min}$ at 60 ${ }^{\circ} \mathrm{C}$ with amyloglucosidase from Aspergillus niger extract and incubated with glucose assay mix (HK and G6P-DH) at pH 5.6.

Table 1. Growth, productivity and yield efficiency for 'Flordaprince' peach trees trained either to central leader (CL) or to Y shape (Y) during $1992-94$.

\begin{tabular}{|c|c|c|c|c|c|c|c|c|c|c|c|c|}
\hline \multirow{2}{*}{$\begin{array}{l}\text { Training } \\
\text { system }\end{array}$} & \multicolumn{3}{|c|}{$\begin{array}{l}\text { TCA } \\
\left(\mathrm{cm}^{2}\right)\end{array}$} & \multicolumn{3}{|c|}{$\begin{array}{l}\text { Yield/tree } \\
(\mathrm{kg})\end{array}$} & \multicolumn{3}{|c|}{$\begin{array}{l}\text { Total yield } \\
\left(\mathrm{t} \cdot \mathrm{ha}^{-1}\right)\end{array}$} & \multicolumn{3}{|c|}{$\begin{array}{l}\text { Yield efficiency } \\
\left(\mathrm{kg} \cdot \mathrm{cm}^{-2} \mathrm{TCA}\right)\end{array}$} \\
\hline & 1992 & 1993 & 1994 & 1992 & 1993 & 1994 & 1992 & 1993 & 1994 & 1992 & 1993 & 1994 \\
\hline$\overline{\mathrm{CL}}$ & 33.9 & 92.8 & 93.5 & 9.0 & 18.1 & 22.2 & 8.4 & 16.8 & 20.6 & 0.27 & 0.20 & 0.24 \\
\hline \multirow[t]{2}{*}{$\mathrm{Y}$} & 21.7 & 47.9 & 60.1 & 6.0 & 9.1 & 17.3 & 11.0 & 16.8 & 32.0 & 0.28 & 0.19 & 0.28 \\
\hline & $* *$ & $* *$ & $* *$ & $* *$ & $* *$ & $*$ & NS & NS & $* *$ & NS & NS & NS \\
\hline
\end{tabular}

$\mathrm{Ns}^{*},{ }^{* *}$ Nonsignificant or significant at $P \leq 0.05$ or 0.01 , respectively, according to Student $t$ test. 


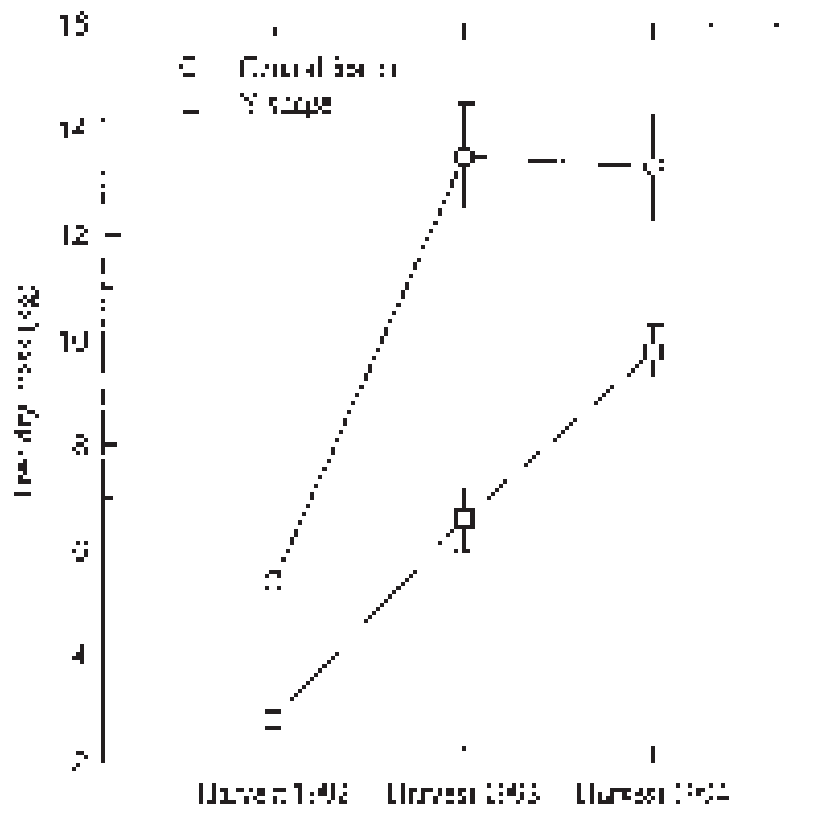

Fig. 1. Dry matter accumulation in the above-ground components (excluding fruit) of 'Flordaprince' single peach trees, trained either to central leader $(\mathrm{O})$ or to $\mathrm{Y}$ shape ( $\square$ ), at fruit harvest in 1992 (12 June), 1993 (10 June), and 1994 (11 June). SE $(n=5)$ bars are visible when larger than symbol.

The absorbance was read at $340 \mathrm{~nm}$.

Data were analyzed using Systat package (Wilkinson, 1990), and means were separated with the Student's $t$ test.

\section{Results}

GrowTH AND PRODUCTIVITY. 'Flordaprince' peach trees trained either to central leader or to Y shape showed significant differences in individual tree growth and productivity, 2 (1992), 3 (1993), and 4 (1994) years after planting. Trees trained to central leader had a significantly $(P \leq 0.01)$ greater growth than Y shape trees, in terms of TCA (Table 1), leaf area (Table 2) and tree dry mass (Fig. 1). However, the two training systems did not differ in terms of yield efficiency (Table 1) or leaf area relative to the ground area allotted to the tree (LAI) (Table 2). On a hectare basis, differences between the two training systems appeared in 1994, when central leader trees did not show any significant increase of dry matter accumulation, while Y shape trees continued to grow almost linearly (Fig. 2). The higher fruit yields of trees trained to central leader did not make up for the lower planting density. In 1994, yield per hectare was significantly $(P \leq 0.01)$ higher $(35 \%)$ for $\mathrm{Y}$ shape than for central leader (Table 1) trees.

Individual trees trained to central leader had the greatest relative growth and fruit yield increment in 1993, when they doubled their leaf area, LAI, and fruit yield and increased 2.5 times in terms of TCA and total dry mass (Table 1, Fig. 1). In 1993, trees trained to central leader were twice the size (leaf area and TCA) and gave twice the yield of Y shape trees. In 1994, tree development of central leader trees leveled off, in terms of dry matter accumulation and TCA increment, with a slight increase in leaf area and fruit yield. Trees trained to $\mathrm{Y}$ shape had the largest relative growth in 1993, but the largest increase in yield in 1994. At this stage, they had reached $60 \%$ of the leaf area (Table 2), $75 \%$ of tree dry mass (Fig. 1), and yielded $\approx 20 \%$ less than central leader trees. However, they were more efficient in terms of fruit dry matter per leaf area. The total dry matter per leaf area was higher for central leader trees in 1992, then it leveled off. By 1994, trees trained to Y shape accumulated more dry matter per leaf area than central leader trees (Table 2).

Fruit fresh and dry weight, TSS, TTA, and sucrose, glucose, and fructose content were not affected by the training system (data not shown).

DRY MATTER PARTITIONING. Total dry mass (excluding fruit) of trees trained to central leader increased 2.5 times from 1992 to 1993 fruit harvest sampling dates. Fruit, leaf, shoots, and 1-yearold wood dry mass doubled in 1993, while the dry mass of the >1year-old wood components increased more than three times (Table 3). At fruit harvest in 1994, trees trained to central leader did not show any further increment in the dry mass of any of the canopy components, except the fruit. Trees trained to $\mathrm{Y}$ shape accumulated significantly $(P \leq 0.01)$ less dry mass in any of the aboveground components, at each of the fruit harvest sampling dates (Table 3). Largest differences occurred in the time course of dry mass allocation into >1-year-old wood components, resulting from the different time required for completing the tree frame.

The dry matter of $>1$-year-old components of $\mathrm{Y}$ shape trees increased 3.5 times in 1993, still being 60\% lower than central leader trees, and doubled again in 1994. At this stage, the dry mass of >1-year-old wood components of Y shape trees was only $20 \%$ less than for central leader.

At all fruit harvest sampling dates, trees trained either to central leader or to Y shape had similar fruit per 1-year-old wood, leaf per 1 -year-old wood, and leaf to shoot dry weight ratios. Fruit per 1year-old wood ratio significantly $(P \leq 0.01)$ increased in 1994 for both the training systems, while the 1 -year-old/>1-year-old wood ratio $(P \leq 0.01)$ decreased with tree growth.

Two and three years after planting, central leader trees partitioned more dry matter to the $>1$-year-old wood components than Y shape trees. Nevertheless, in 1994 the dry matter partitioned to the $>1$-year-old wood components represented $60 \%$ of the total tree mass (excluding fruit) in both the training systems. The relative contribution of the other woody (1-year-old wood) and vegetative (shoot and leaf) components to the dry mass of the tree did not change significantly with the training system, but decreased with tree age (Table 4$)$.

Y shape trees had a higher $(P \leq 0.05) \mathrm{HI}$ than central leader trees at fruit harvest sampling dates in 1992 and 1994, HI being 34\% and

Table 2. Leaf area, LAI, total dry weight per unit leaf area (TDW/LA) and fruit dry weight per unit leaf area (FDW/LA) for 'Flordaprince' peach trees trained either to central leader (CL) or Y shape (Y).

\begin{tabular}{|c|c|c|c|c|c|c|c|c|c|c|c|c|}
\hline \multirow{2}{*}{$\begin{array}{l}\text { Training } \\
\text { system }\end{array}$} & \multicolumn{3}{|c|}{$\begin{array}{l}\text { Leaf area } \\
\qquad\left(\mathrm{m}^{2}\right)\end{array}$} & \multicolumn{3}{|c|}{ LAI } & \multicolumn{3}{|c|}{$\begin{array}{c}\text { TDW/LA } \\
\left(\mathrm{g} \mathrm{m}^{-2}\right)\end{array}$} & \multicolumn{3}{|c|}{$\begin{array}{c}\text { FDW/LA } \\
\left(\mathrm{g} \mathrm{m}^{-2}\right)\end{array}$} \\
\hline & 1992 & 1993 & 1994 & 1992 & 1993 & 1994 & 1992 & 1993 & 1994 & 1992 & 1993 & 1994 \\
\hline$\overline{\mathrm{CL}}$ & 26.6 & 53.1 & 58.3 & 2.4 & 4.9 & 5.4 & 248.1 & 318.2 & 303.6 & 45.1 & 45.2 & 49.7 \\
\hline \multirow[t]{2}{*}{$\mathrm{Y}$} & 18.4 & 27.1 & 33.9 & 3.4 & 5.0 & 6.3 & 200.0 & 287.8 & 353.9 & 43.5 & 44.3 & 67.8 \\
\hline & $* *$ & $* *$ & $* *$ & NS & NS & NS & $*$ & NS & $*$ & NS & NS & $* *$ \\
\hline
\end{tabular}

Nonsignificant or significant at $P \leq 0.05$ or 0.01 , respectively, according to Student $t$ test. 


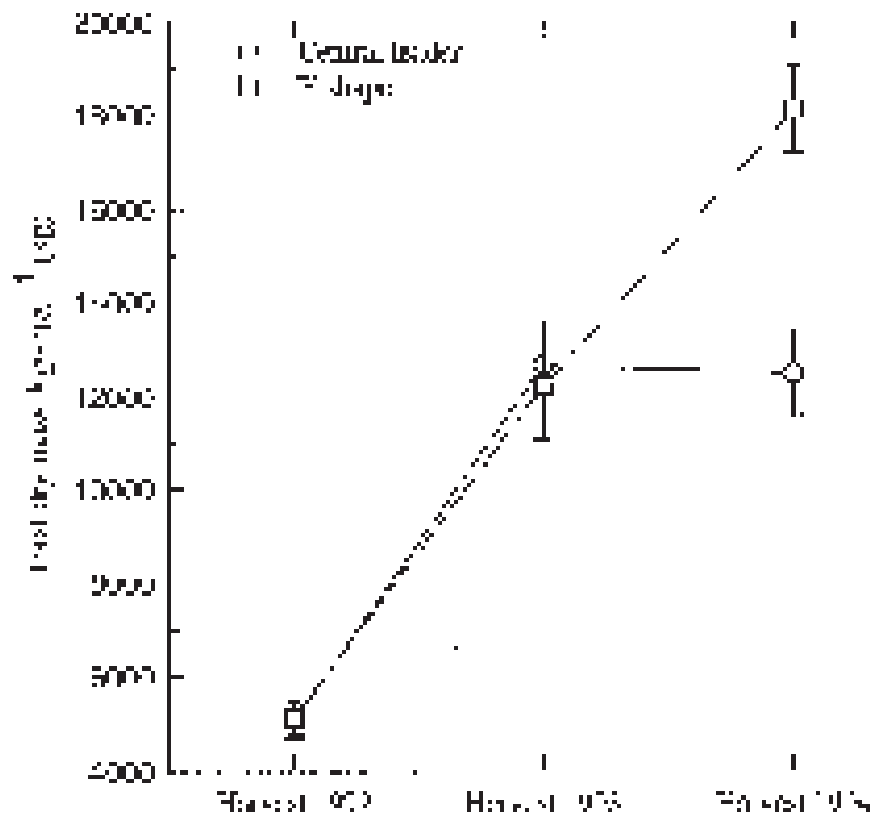

Fig. 2. Total (kg ha $\left.{ }^{-1}\right)$ dry above-ground dry matter (excluding fruit) of 'Flordaprince' peach trees, trained either to central leader $(\bigcirc)$ or to Y shape $(\square)$, at fruit harvest in 1992 (12 June), 1993 (10 June), and 1994 (11 June). SE $(\mathrm{n}=5)$ bars are visible when larger than symbol.
$42 \%$ for central leader trees, and $40 \%$ and $50 \%$ for Y shape trees; in 1992 and 1994, respectively. In 1993, there was no significant difference between the training systems.

SEASONAL GROWTH AND STARCH MOBILIZATION (1994). Leaf area was higher for central leader than Y shape trees at all times during the fruit development period (Fig. 3). By fruit set and pit hardening leaf area had reached $32 \%$ and $45 \%$ of what it was at harvest in central leader trees, and $34 \%, 60 \%$ in Y shape trees. Preharvest summer pruning removed $1.6 \pm 0.2,1.8 \pm 0.3,2.4 \pm 0.5 \mathrm{~m}^{2}$ of leaf area in central leader trees, and $0.9 \pm 0.06,1.3 \pm 0.5,1.8 \pm 0.2 \mathrm{~m}^{2}$ of leaf area in Y shape trees in 1992, 1993, and 1994, respectively. Canopy relative growth rate increased significantly during stage

- III of fruit development for central leader trees. Leaf area/fruit number ratio became significantly $(P \leq 0.01)$ higher in central leader during most of stage III (Fig. 4). On per hectare basis, Y shape trees had a higher LAI than central leader trees, from fruit set to pit hardening, and no difference occurred at the time of fruit - harvest(Fig. 5). Leaf to fruit number ratio (unit leaf area $=28 \pm 1.23$ $\mathrm{cm}^{2}$ ) was $39 \pm 2.6$ and $68 \pm 3.4$ for $Y$ shape trees, and $32 \pm 2.2$ and $95 \pm 8.7$ for central leader trees, at pit hardening and fruit harvest respectively. From fruit set to pit hardening, most of the annual growth of canopy components was partitioned to the vegetative growth (Fig. 6). At pit hardening, the fruit accounted for $30 \%$ of the annual dry matter, and central leader trees partitioned significantly $(P \leq 0.05)$ more dry matter to the fruit than Y shape trees. At the

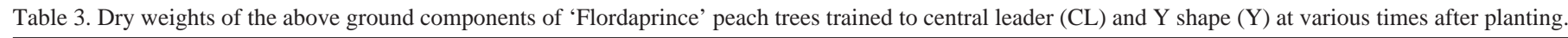

\begin{tabular}{|c|c|c|c|c|c|c|c|c|c|c|c|c|}
\hline \multirow{4}{*}{$\begin{array}{l}\text { Sampling } \\
\text { time }\end{array}$} & \multicolumn{12}{|c|}{ Dry matter content/tree $(\mathrm{kg})$} \\
\hline & & & & & & & & Wo & & & & \\
\hline & \multicolumn{2}{|c|}{ Fruit } & \multicolumn{2}{|c|}{ Leaves } & \multicolumn{2}{|c|}{ Shoot } & \multicolumn{2}{|c|}{ 1-Year } & \multicolumn{2}{|c|}{ 2-Year } & \multicolumn{2}{|c|}{ Total } \\
\hline & $\mathrm{CL}$ & Y & $\mathrm{CL}$ & Y & $\mathrm{CL}$ & $\mathrm{Y}$ & $\mathrm{CL}$ & Y & $\mathrm{CL}$ & $\mathrm{Y}$ & $\mathrm{CL}$ & $\mathrm{Y}$ \\
\hline \multicolumn{13}{|l|}{ Harvest } \\
\hline 1992 & $1.2 \pm 0.02$ & $0.8 \pm 0.02$ & $1.6 \pm 0.06$ & $0.7 \pm 0.06$ & $0.7 \pm 0.05$ & $0.4 \pm 0.01$ & $0.9 \pm 0.03$ & $0.8 \pm 0.06$ & $2.2 \pm 0.2$ & $0.3 \pm 0.04$ & $6.6 \pm 0.3$ & $3.6 \pm 0.2$ \\
\hline \multicolumn{13}{|l|}{ Dormancy } \\
\hline $1992-93$ & --- & --- & --- & --- & --- & --- & $1.3 \pm 0.03$ & $0.7 \pm 0.06$ & $5.8 \pm 0.6$ & $2.1 \pm 0.03$ & $7.1 \pm 0.7$ & $2.8 \pm 0.3$ \\
\hline \multicolumn{13}{|l|}{ Harvest } \\
\hline 1993 & $2.4 \pm 0.1$ & $1.2 \pm 0.01$ & $3.3 \pm 0.02$ & $1.9 \pm 0.3$ & $1.1 \pm 0.08$ & $0.6 \pm 0.03$ & $1.7 \pm 0.02$ & $0.9 \pm 0.06$ & $8.4 \pm 0.7$ & $3.2 \pm 0.02$ & $16.9 \pm 1.0$ & $7.8 \pm 0.2$ \\
\hline \multicolumn{13}{|l|}{ Dormancy } \\
\hline 1993-94 & --- & --- & --- & --- & --- & --- & $1.3 \pm 0.2$ & $0.8 \pm 0.1$ & $9.2 \pm 0.7$ & $6.4 \pm 1.0$ & $10.6 \pm 0.9$ & $7.2 \pm 0.6$ \\
\hline \multicolumn{13}{|l|}{ Harvest } \\
\hline 1994 & $2.9 \pm 0.3$ & $2.3 \pm 0.02$ & $2.7 \pm 0.1$ & $1.8 \pm 0.7$ & $0.9 \pm 0.05$ & $0.5 \pm 0.01$ & $1.5 \pm 0.2$ & $0.9 \pm 0.1$ & $8.8 \pm 0.3$ & $6.6 \pm 0.8$ & $16.8 \pm 1.0$ & $12.1 \pm 1.1$ \\
\hline
\end{tabular}

Table 4. Percentage of total dry weight in the components of 'Flordaprince' peach trees trained to central leader (CL) or Y shape (Y) at various time after planting.

\begin{tabular}{|c|c|c|c|c|c|c|c|c|c|c|}
\hline \multirow{4}{*}{$\begin{array}{l}\text { Sampling } \\
\text { time }\end{array}$} & \multicolumn{10}{|c|}{ Total dry wt (\%) } \\
\hline & & & & & & & & & & \\
\hline & \multicolumn{2}{|c|}{ Fruit } & \multicolumn{2}{|c|}{ Leaves } & \multicolumn{2}{|c|}{ Shoot } & \multicolumn{2}{|c|}{ 1-year } & \multicolumn{2}{|c|}{ 2-year } \\
\hline & $\mathrm{CL}$ & $\mathrm{Y}$ & $\mathrm{CL}$ & $\mathrm{Y}$ & $\mathrm{CL}$ & $\mathrm{Y}$ & $\mathrm{CL}$ & $\mathrm{Y}$ & $\mathrm{CL}$ & $\mathrm{Y}$ \\
\hline \multicolumn{11}{|l|}{ Harvest } \\
\hline 1992 & $18.2 \pm 0.7$ & $22.2 \pm 0.6$ & $24.2 \pm 0.5$ & $19.4 \pm 1.4$ & $10.6 \pm 0.3$ & $11.1 \pm 0.4$ & $13.6 \pm 0.7$ & $22.0 \pm 1.3$ & $33.4 \pm 2.1$ & $25.3 \pm 1.4$ \\
\hline \multicolumn{11}{|l|}{ Dormancy } \\
\hline 1992-93 & --- & --- & --- & --- & --- & --- & $18.3 \pm 2.0$ & $25.0 \pm 1.4$ & $81.7 \pm 3.1$ & $75.0 \pm 2.7$ \\
\hline \multicolumn{11}{|l|}{ Harvest } \\
\hline 1993 & $14.2 \pm 0.8$ & $15.4 \pm 0.4$ & $19.5 \pm 0.9$ & $24.4 \pm 0.3$ & $6.5 \pm 0.4$ & $7.7 \pm 0.5$ & $10.0 \pm 1.1$ & $11.5 \pm 2.1$ & $49.8 \pm 1.9$ & $41.0 \pm 2.4$ \\
\hline \multicolumn{11}{|l|}{ Dormancy } \\
\hline 1993-94 & --- & --- & --- & --- & --- & --- & $12.4 \pm 1.0$ & $11.2 \pm 0.7$ & $87.6 \pm 2.2$ & $88.8 \pm 3.4$ \\
\hline \multicolumn{11}{|l|}{ Harvest } \\
\hline 1994 & $18.1 \pm 0.6$ & $19.0 \pm 0.9$ & 17.40 .8 & $14.9 \pm 0.5$ & $5.6 \pm 0.5$ & $1.1 \pm 0.1$ & $4.2 \pm 0.3$ & $7.4 \pm 0.6$ & $49.5 \pm 1.2$ & $54.6 \pm 0.9$ \\
\hline
\end{tabular}




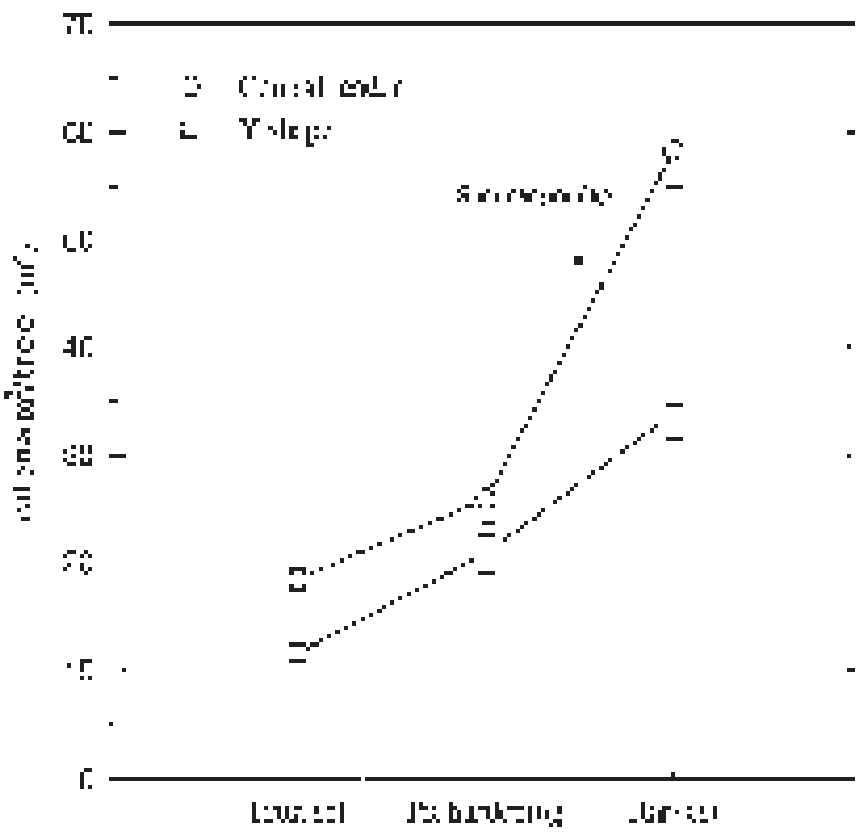

Fig. 3. Seasonal pattern of leaf area development in 'Flordaprince' peach trees, trained either to central leader $(O)$ or to Y shape $(\square)$, during the 1994 growing season, from fruit set (10 Mar.) to pit hardening (27 Apr.) and fruit harvest (11 June). SE $(n=5)$ bars are visible when larger than symbol.

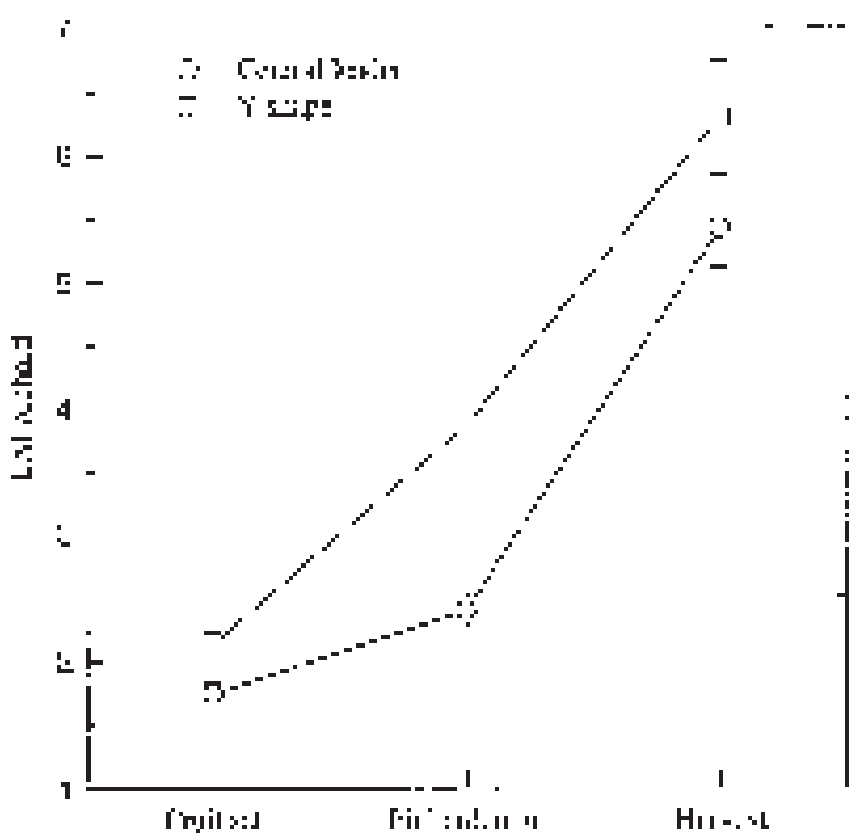

Fig. 5. Seasonal pattern of LAI development in 'Flordaprince' peach central leader (O) and Y shape ( $\square$ ) training systems, during the 1994 growing season, from fruit set (10 Mar.) to pit hardening (27 Apr.) and fruit harvest (11 June). SE ( $\mathrm{n}=5)$ bars are visible when larger than symbol.

end of stage II, individual fruit dry weight was $3.1 \pm 0.2 \mathrm{~g}$ for central leader and $2.8 \pm 0.3$ for $Y$ shape trees. Postharvest summer pruning removed $2.1 \pm 0.3,3.5 \pm 0.4,3.6 \pm 0.8 \mathrm{~m}^{2}$ of leaf area in central leader trees, and $0.7 \pm 0.04,1.5 \pm 0.3,2.1 \pm 0.4 \mathrm{~m}^{2}$ of leaf area in Y shape trees in 1992, 1993 and 1994, respectively. On the whole, summer prunings accounted for $10 \%$ of tree leaf area, in both Y shape and central leader trees.

Vegetative (leaf and shoot) dry mass per ground area was unaffected by the training system at 1992 and 1993 fruit harvest

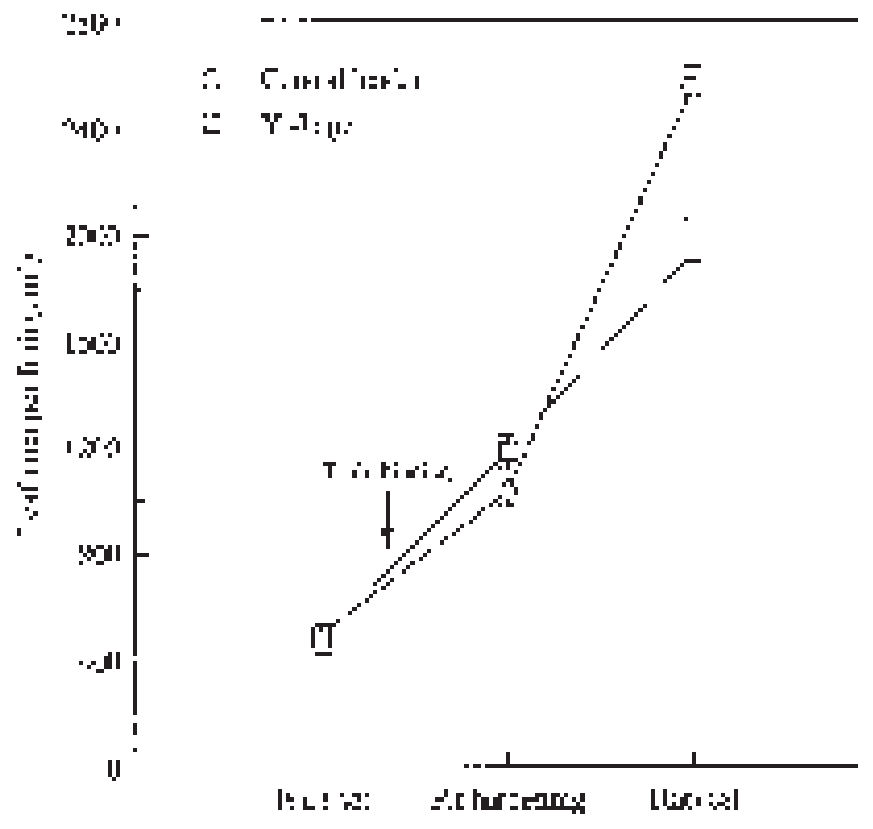

Fig. 4. Pattern of leaf area per fruit ratio in 'Flordaprince' peach trees, trained either to central leader $(\bigcirc)$ or to Y shape $(\square)$, during the 1994 growing season, from fruit set (10 Mar.) to pit hardening (27 Apr.) and fruit harvest (11 June). SE ( $n=5)$ bars are visible when larger than symbol. Fruit thinning was accomplished 3 weeks after fruit set (30 Mar.).

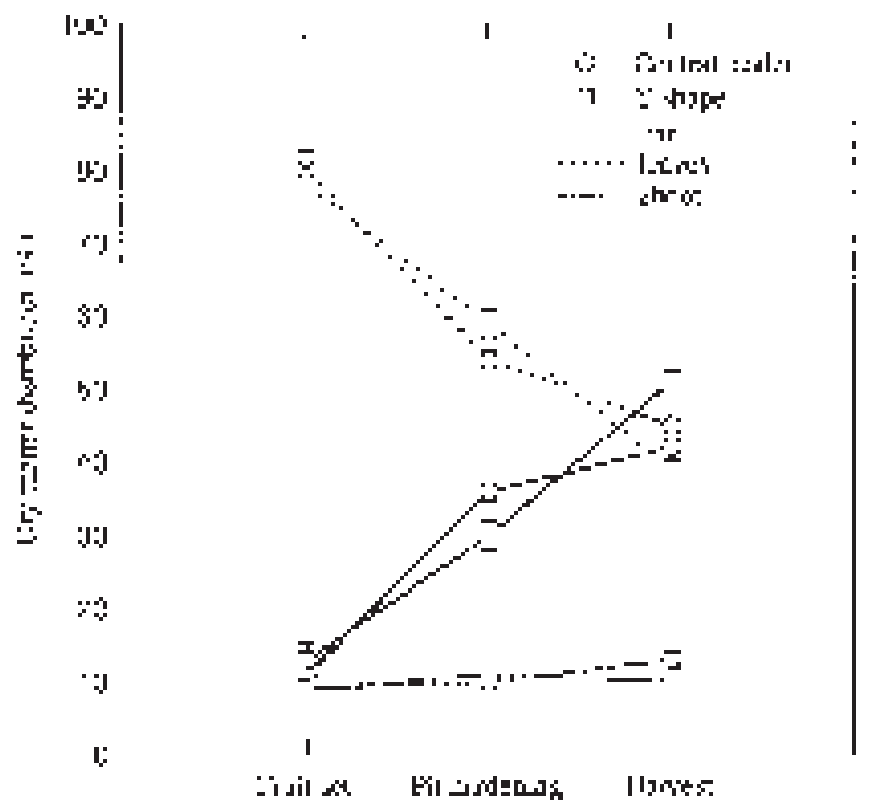

Fig. 6. Above-ground dry matter distribution between fruit, leaves, and shoots of 'Flordaprince' peach trees, trained either to central leader $(\bigcirc)$ or to Y shape ( $\square$ ), during the 1994 growing season, at fruit set (10 Mar.), pit hardening (27 Apr.), and fruit harvest (11 June). SE $(n=5)$ bars are visible when larger than symbol.

sampling dates (Fig. 7). However, Y shape trees had the highest $(P$ $\leq 0.01)$ vegetative and fruit dry mass per unit ground area in 1994 . Vegetative mass exceeded fruit mass for both training systems, but not for Y shape trees in 1994.

Training system did not significantly affect the seasonal pattern of starch content in >1-year-old wood and 1-year-old components of the canopy, from the date of fruit harvest sampling date in 1993 through 1994 fruit growing season (Fig. 8). The highest starch concentration was found in the $>1$-year-old wood components on 
each sampling date; central leader trees having a higher starch content than Y shape trees, from dormancy to pit hardening. Starch content declined sharply ( $55 \%$ to $65 \%$ ) from dormancy to fruit set, and continued to decrease during the fruit development period, particularly in the 1-year-old wood. From fruit set to harvest, the rate of starch depletion in >1-year-old wood components was higher for central leader than Y shape trees, and, at fruit harvest, both training systems had the same starch content in $>1$-year-old

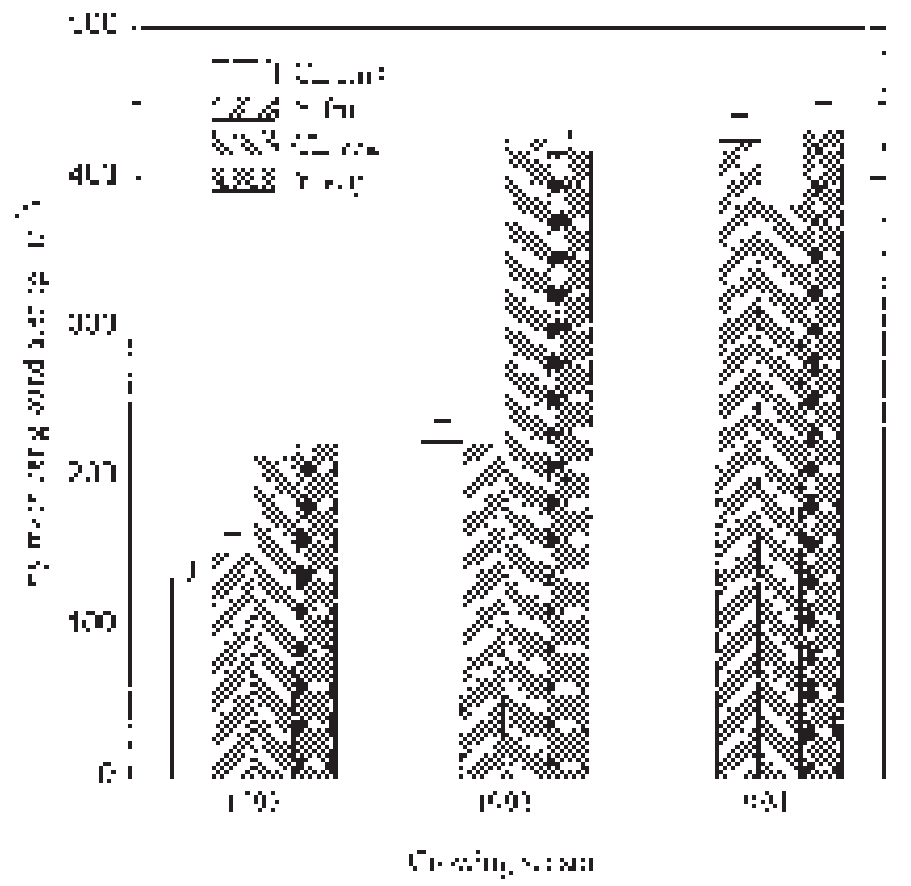

Fig. 7. Fruit and vegetative (leaf and shoots) dry mass per ground area of 'Flordaprince' peach trees, trained either to central leader or to Y shape, at fruit harvest in 1992 (12 June), 1993 (10 June), and 1994 (11 June).

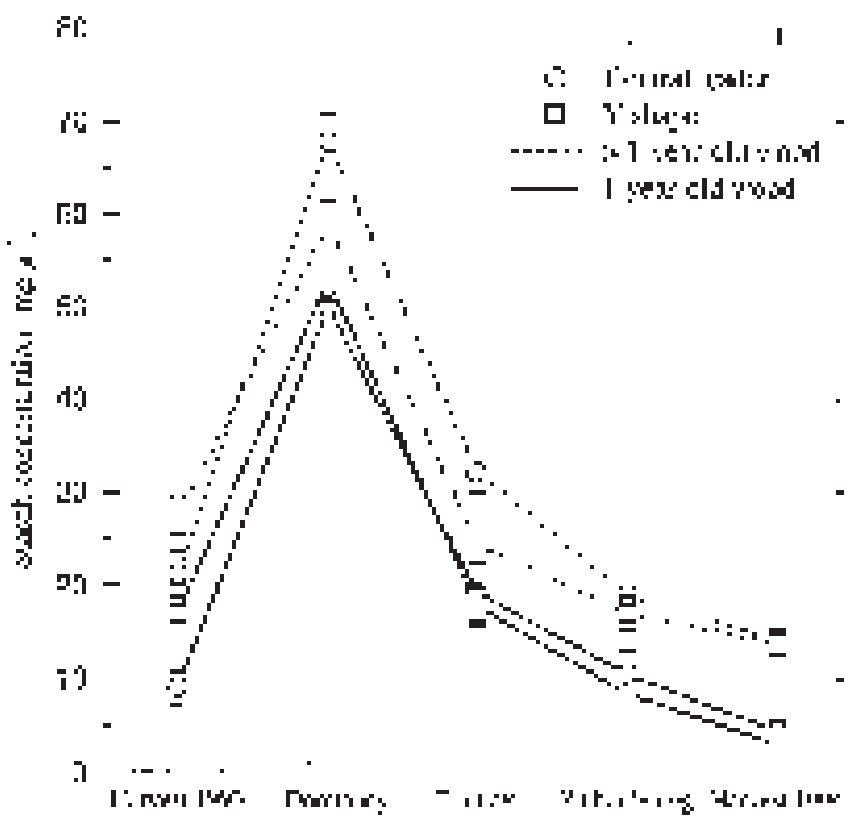

Fig. 8. Starch concentration in 1-year-old wood and in $>1$-year-old wood of 'Flordaprince' peach trees, trained either to central leader $(O)$, or to Y shape $(\square)$, at fruit harvest in 1993 (10 June), dormancy (12 Jan. 1994) and at fruit set (10 March 1994), pit hardening (27 Apr. 1994), and fruit harvest (11 June 1994). SE $(n=5)$ bars are visible when larger than symbol. wood and 1-year-old component. Harvest values were $20 \%$ and $25 \%$ of dormancy values in $>1$-year-old wood components and $4.5 \%$ and $3.5 \%$ in 1-year-old wood, for central leader and Y shape trees, respectively.

\section{Discussion}

Four years after planting, Y shape trees had a higher fruit dry matter per ground area and per leaf area, and a higher HI than central leader trees. Cumulative fruit yields and total tree dry mass per hectare (1992-94) were also significantly higher for the Y shape than for central leader training system. However, Y shape trees had about twice as many trees per hectare as central leader trees yet their yield per hectare was only $55 \%$ greater. A high efficiency of Y shape training system has been also encountered in apple for Y-trellis/M26 compared to Central leader/M9/MM111 (Robinson and Lakso, 1991). Central leader trees approached their maximum cropping potential earlier than $\mathrm{Y}$ shape trees, as indicated by the evolution of tree size, dry mass and fruit yield per hectare. Even if $\mathrm{Y}$ shape trees required more time and more pruning to accomplish their structure (Corelli and Coston, 1991), yields per hectare were never lower than for central leader. TCA was a good estimator of tree above-ground dry mass $\left(R^{2}=0.91\right)$. The partitioning index ( $\mathrm{kg}$ fruit $/ \mathrm{cm}^{2}$ increase in TCA) calculated over the three years period was lower than for apple trees (Robinson and Lakso, 1991) (0.85 for central leader and 1.2 for Y shape). Yield efficiency expressed as fruit yield/ trunk cross-sectional area did not account for the significant different in cropping efficiency that resulted in terms of fruit dry weight per leaf or ground area. Chalmers and van den Ende (1975) indicated that the growth rate of the tree in terms of butt circumference levels off after the commencement of cropping in their experiment that began 6 years after planting. In our experiment there was a tendency for TCA to decrease in growth with increasing cropping performance, particularly from 3 to 4 years after planting. The HIs reported here for 4year-old trees of an early ripening cultivar trained to $\mathrm{Y}$ shape were higher than those reported for 8-year-old trees of 'Loring' late ripening peach trained to an open vase (Miller and Walsh, 1988). If we consider that 'Flordaprince' is much smaller than 'Loring' in terms of fruit dry weight, our HI values clearly indicate the higher efficiency of $\mathrm{Y}$ shape high density plantings compared to open vase. This supports the hypothesis (Chalmers and van den Ende, $1975)$ that high yields of high density orchards depend on a reduction in the size or age at which the trees attain their optimum carbon partition into the fruit. Miller and Walsh (1988) indicated that vegetative growth occurs most rapidly during stage I and stage II of fruit growth, while very little growth occurs during stage III. However, this is not the case for an early ripening cultivar like 'Flordaprince'. In this case, fruit growth occurred from early March to early June, simultaneously with the grand period of shoot extension and leaf area development. DeJong et al. (1987) found a major peak of shoot growth rate during stage III of fruit growth for 'June Lady' early ripening peach. This was also the case for 'Flordaprince' but the simultaneous period of highest fruit demand (stage III) apparently reduced vegetative growth during this period, more in Y shape than in central leader trees. The central leader trees had the greatest leaf area and shoot dry weight increment from pit hardening to fruit harvest. This greater growth did not involve significant changes in fruit size and overall quality. Weinberger (1931) indicated a threshold value of 75 leaves per fruit for optimum fruit size and flavor for 'Elberta' and 'Late Crawford' peaches. More recently, Sansavini et al. (1985) indicated a linear relationship between leaf to fruit number ratio (in the range of 15 
to 55 leaves per fruit) and fruit quality for 8-year-old high yielding clingstone peach 'Loadel'. In central leader trees we found, at harvest time, a leaf/fruit number ratio well above those threshold values. On the other hand, leaf/fruit ratio in Y shape trees were within the optimal range (Sansavini et al., 1985). Y shape trees had a lower total tree leaf area and tree dry mass, but a higher vegetative potential in terms of vegetative dry mass per ground area than central leader trees. High densities do not reduce vegetative potential significantly, even at closer spacings (Chalmers et al., 1981) and appropriate canopy management remains the major tool to avoid vegetative vs. fruit growth competitive demand (Grossman and DeJong, 1995). Early fruit thinning coupled with preharvest summer pruning are required to reduce competition between vegetative and fruit sink demands (Grossman and DeJong, 1995).

The mobilization of starch from the storage canopy pools is well documented for peach (Caruso et al., 1997b; Dowler and King, 1966) since early demand for fruit and vegetative growth largely depends on reserves (Jordan and Habib, 1996). Our data, which do not include the contribution of the root system, indicate that, as for apple (Stutte et al., 1994), the training system influenced the mobilization of starch from the storage pools of the canopy, since a higher mobilization occurred from >1-year-old wood components of central leader trees, from dormancy to pit hardening. The higher starch concentration found, during dormancy, in >1-yearold wood components of central leader trees may be related to their greater leaf area which may lead to a higher carbohydrate accumulation after fruit harvest (Gaudillère et al., 1992).

In conclusion, $\mathrm{Y}$ shape produced more fruit yields per hectare than central leader, with no reduction in fruit size. Y shape trees had a higher harvest index and fruit dry mass per unit area than central leader trees. Central leader trees approached their cropping potential three years after being planted but were less efficient in terms of carbon partitioned to fruit, mostly because of extensive vegetative growth occurring during stage III of fruit growth. Appropriate management (early fruit thinning and preharvest summer pruning) is needed to maintain fruit quality for early ripening peaches.

\section{Literature Cited}

Caruso, T., P. Inglese, D. Giovannini, and E. Turci. 1995. Rootstock influence on dry matter and minerals above-ground content and partitioning in 'Maravilha' peach trees. Acta Hort. 383:105-114.

Caruso, T., D. Giovannini, F.P. Marra, and F. Sottile. 1997a. Two new planting systems for early ripening peaches (Prunus persica L. Batsch): Yield and fruit quality in four low chill cultivars, J. Hort. Sci. 72: 873-883.

Caruso, T., P. Inglese, M. Sidari, and F. Sottile. 1997b. Rootstock influences seasonal dry matter and carbohydrate content and partitioning in above-ground components of 'Flordaprince' peach trees. J. Amer. Soc. Hort. Sci. 122:673-679.

Chalmers, D.J. 1975. The Tatura trellis: will it revolutionize fruit growing? Victorian Horticulture Digest 65: 12-40.

Chalmers, D.J. 1989. An analysis of growth and productivity of peach trees. Acta Hort. 254:100.

Chalmers, D.J. and B. van den Ende. 1975. Productivity of peach trees: Factors affecting dry-weight distribution during tree growth. Ann. Bot. 39:423-32.

Chalmers, D.J., P.D. Mitchell, and L. van Heek. 1981. Control of peach tree growth and productivity by regulated water supply, plant density and summer pruning. J. Amer. Soc. Hort. Sci. 106:307-312.

Corelli Grappadelli, L. and D.C. Coston. 1991. Thinning patterns and environment in peach tree canopies influence fruit quality. HortScience 26:1464-66.
De Salvador, F.R. and T.M. DeJong. 1989. Observations of sunlight interception and penetration into the canopies of peach trees in different planting densities and pruning configurations. Acta Hort. 254:341-346.

DeJong, T.M. and J.F. Doyle. 1984. Cropping efficiency, dry matter and nitrogen distribution in mature genetic dwarf and standard peach trees. Acta Hort. 146:89-95.

DeJong, T.M. and J.F. Doyle. 1985. Seasonal relationship between leaf nitrogen content (photosynthetic capacity) and the leaf canopy light exposure in peach (Prunus persica). Plant Cell Environ. 8:701-706.

DeJong, T.M., J.F. Doyle, and K.R. Day. 1987. Seasonal patterns of reproductive and vegetative sink activity in early and late maturing peach (Prunus persica) cultivars. Physiol. Plant. 71:83-88.

Dowler, W.M. and F.D. King. 1966. Seasonal changes in starch and soluble sugar content of dormant peach tissues. Proc. Amer. Soc. Hort. Sci. 89:80-84.

Gaudillère, J.P., A. Moing, and F. Carbonne. 1992. Vigor and nonstructural carbohydrates in young prune trees. Sci. Hort. 51:197-211.

George, A.P., S. Hieke, T. Rasmussen, and P. Ludders. 1996. Early shading reduces fruit yield and late shading reduces quality in low-chill peach Prunus persica (L.) Batsch in subtropical Australia. J. Hort. Sci. 4:561-571.

Glenn, D.M. and R. Scorza. 1992. Reciprocal graft of standard and dwarf peach alter dry matter partitioning and root physiology. HortScience 27:241-243.

Grossman, Y.L. and T.M. DeJong. 1992. Peach: A simulation model of reproductive and vegetative growth in peach trees. Tree Physiol. 14:329345.

Grossman, Y.L. and T.M. DeJong. 1995. Maximum vegetative growth potential and seasonal pattern of resource dynamics during peach growth. Ann. Bot. 76:473-482.

Jordan, M.O. and R. Habib. 1996. Mobilizable carbon reserves in young peach trees as evidenced by trunk girdling experiments. J. Expt. Bot. 294:79-87.

Inglese, P. and F.R. De Salvador. 1996. Gestione dell'albero e qualità dei frutti nel pesco: Aspetti fisiologici e tecnici. Rivista Frutticolt. 4:64-72.

Loreti, F., R., Massai, and S. Morini. 1990. Observation on canopy development in nectarine high density planting system. Adv. Hort. Sci. 4:113-117.

Marini, R.P. and D.L. Sowers. 1990. Net photosynthesis, specific leaf weight and flowering of peach as influenced by shade. HortScience 25:331-334.

Marini, R.P., D.L., Sowers, and M.C. Marini. 1991. Peach fruit quality is affected by shade during final swell of fruit growth. J. Amer. Soc. Hort. Sci. 116: 383-389.

Miller, A.N. and C.S. Walsh. 1988. Growth and seasonal partitioning of dry matter in eight-year-old 'Loring' peach trees. J. Amer. Soc. Hort. Sci. 113:309-314.

Robinson, T.L. and A.N. Lakso. 1991. Bases of yield and production efficiency in apple orchard systems. J. Amer. Soc. Hort. Sci. 116:188194.

Sansavini, S., L. Corelli, and L. Giunchi. 1985. Peach yield efficiency related to tree shape. Acta Hort. 173:139-158.

Scorza, R., L. Zailong, G.W. Lightner, and L.E. Gilreath. 1986. Dry matter distribution and responses to pruning within a population of standard, semidwarf, compact and dwarf peach seedlings. J. Amer. Soc. Hort. Sci. 111:541-545.

Stutte, G.W., T.A. Baugher, S.P. Walter, D.W. Leach, D.M. Glenn, and T.J. Tworkoski. 1994. Rootstock and training system affect dry-matter and carbohydrate distribution in 'Golden Delicious' apple trees. J. Amer. Soc. Hort. Sci. 119:492-497.

Weinbaum, S.A., S.M. Southwick, K. Shackel, T.T. Muraoka, W. Krueger, and J.T. Jager. 1989. Photosynthetic photon flux influence macroelement weight and leaf dry weight per unit of leaf area in prune tree canopies. J. Amer. Soc. Hort. Sci. 114:720-723.

Weinberger, J.H. 1931. The relation of leaf area to size and quality of peaches. Proc. Amer. Soc. Hort. Sci. 28:18-22.

Wilkinson, L. 1990. SYSTAT: The system for statistics. Evanston, Ill. 